\title{
Faktor Yang Mempengaruhi Flame Cutting CNC Dan Waktu Pendinginan Terhadap Kekerasan
}

\author{
Mustafa $^{1}$, Sudarno ${ }^{2}$ \\ ${ }^{\text {I} P r o g r a m ~ S t u d i ~ T e k n i k ~ M e s i n, ~ U n i v e r s i t a s ~ M e r d e k a ~ M a d i u n, ~ J l . ~ S e r a y u ~ N o .79, ~ M a d i u n, ~} 63133$ \\ E-mail:mustafa@unmer-madiun.ac.id \\ ${ }^{2}$ Program Studi Teknik Mesin, Universitas Merdeka Madiun, Jl. Serayu No.79, Madiun, 63133 \\ E-mail: sudarno@unmer-madiun.ac.id
}

\begin{abstract}
In material that is subjected to heat treatment or workmanship such as in the welding process or flame cutting cutting, it will experience structural changes and mechanical properties. Changes in mechanical properties will cause losses such as: material becomes hard and brittle, although tensile strength and wear resistance increases. In this study an analysis of the factors affecting flame cutting cnc and cooling time against hardness was carried out. This study aims to determine the factors that influence the change in hardness on the results of flame cutting cutting. The study was conducted with three different treatments. The results of flame cutting cutting are cooled with 10 seconds, 25 seconds and 50 seconds respectively. Hardness data collection was carried out at a distance of $2 \mathrm{~mm}, 10 \mathrm{~mm}, 20 \mathrm{~mm}, 30 \mathrm{~mm}, 40 \mathrm{~mm}$ and $50 \mathrm{~mm}$. The experimental results showed that the hardness value of SS 400 material at 10 seconds cooling time resulted in an average hardness of testing $1=76 \mathrm{HRB}$, testing $2=76 \mathrm{HRB}$, testing $3=76 \mathrm{HRB}$. At 25 seconds cooling time produces the average hardness from testing $1=74.83 \mathrm{HRB}$, testing $2=74.66 \mathrm{HRB}$, testing $3=74.33 \mathrm{HRB}$. And the 50-second cooling time produces the average hardness of the test $1=73.66 \mathrm{HRB}$, testing $2=73.33 \mathrm{HRB}$, testing $3=7658 \mathrm{HRB}$.
\end{abstract}

Keywords—: flame cutting; SS 400; hardness.

\section{PENDAHULUAN}

Di era digital 4.0 hampir semua organisasi menggunakan sarana teknologi informasi untuk melaksanakan kegiatannya. Banyak perusahaan yang tersingkir akibat adanya pergeseran penggunaan sarana informasi dan teknologi karena terlambat dalam berinovasi. Sistem informasi adalah suatu sistem dalam suatu organisasi yang mempertemukan kebutuhan pengolahan transaksi harian yang mendukung fungsi operasi organisasi yang bersifat manajerial dengan kegiatan strategi dari suatu organisasi untuk dapat menyediakan kepada pihak luar tertentu dengan informasi yang diperlukan untuk pengambilan keputusan. Definisi sistem informasi menurut Abdul Kadir adalah "sistem informasi adalah kerangka kerja yang mengkoordinasikan sumber daya (manusia, komputer) untuk mengubah masukan (input) menjadi keluaran (informasi), guna mencapai sasaran-sasaran perusahaan". Peranan sistem informasi adalah membantu mengendalikan dan mengorganisasikan aktivitas aktivitas dari sub sistem - sub sistem dalam organisasi sehingga membantu organisasi tersebut dalam mencapai tujuannya (Lipursari, 2012).

Perkembangan dunia industri saat ini tidak terlepas dari peran teknologi yang terus maju dan berkembang pesat searah dengan perkembangan zaman. Semua jenis material baik logam maupun nonlogam dapat digunakan oleh industri setelah mengalami berbagai proses pengolahan seperti; peleburan, pengecoran, pencetakan, pengelasan, perlakuan permukaan, pengerjaan panas, pengerjaan dingin, pemotongan dan perakitan. Salah satu proses pengolahan bahan baku industri tersebut yaitu dengan proses pemotongan. . Pemotongan flame cutting $\mathrm{CNC}$ adalah proses pemisahan logam untuk membentuk komponen baja sesuai kebutuhan. Dari berbagai media pemotongan, pemotongan dengan mesin flame cutting CNC termasuk alternatif pemotongan tercepat. Proses pemotongan mempunyai keuntungan dan kerugian perubahan struktur dari hasil perlakuan panas dan media pendinginan yang digunakan. Dalam hal ini akibat dari pemotongan flame cutting CNC yang menimbulkan panas yang mencapai titik leleh pada logam, sehingga berdampak perubahan struktur dari logam tersebut.

Adapun yang menjadi tujuan penelitian ini adalah untuk mendapatkan berapa besar perubahan kekerasan akibat proses pemotongan.

Beberapa penelitian terdahulu telah dilakukan. Agus (2004), "Pemotongan dengan menggunakan oxygen flame cutting CNC adalah pemotongan yang terjadi karena adanya reaksi antara oksigen dan baja". Pada permulaan pemotongan baja dipanaskan dulu dengan api oxygen flame cutting CNC sampai mencapai suhu antara sekitar $\left(800^{\circ} \mathrm{C}-900^{\circ} \mathrm{C}\right)$. Kemudian gas oksigen tekanan tinggi disemburkan kebagian yang dipanaskan, dan terjadilah proses pembakaran yang membentuk oksida baja. Karena titik cair oksida baja lebih rendah dari baja, maka oksida tersebut mencair dan terhembus oleh gas sehingga terjadilah pemotongan.

Proses pemotongan flame cutting CNC terjadi perubahan struktur mikro atom pada material yang di potong, hal ini terjadi akibat proses pemanasan yang mencapai suhu antara sekitar $\left(800^{\circ} \mathrm{C}-900^{\circ} \mathrm{C}\right)$. Kekerasan material juga mengalami perubahan, karenan proses pendinginan yang terjadi setelah pemotongan menyebabkan perubahan kekerasan material. 
Mesin flame cutting CNC dapat di progam untuk memotong plat atau komponen dalam berbagai bentuk atau desain tertentu dan menerapkan sistem yang sama dengan mesin potong CNC Gatry. Mesin ini dapat diprogam secara langsung memotong berbagai desain plat atau komponen yang menggunakan progam G-kode, yang dibuat operator melalui progam atau nesting software kemudian di input kedalam mesin melalui USB port.

\section{METODE PENELITIAN}

Bahan dan Alat

Spesifikasi bahan uji Baja SS 400

- Klasifikasi : Baja karbon rendah

- Nilai kekerasan : $74-76 \mathrm{HBR}$

- Meltingpoint : $1412{ }^{\circ} \mathrm{C}$

- Densty : $7860 \mathrm{~kg} / \mathrm{m}^{3}$

Alat penelitian

a. Mesin Flame Cutting CNC AUPAL MS - 4000 LPG

b. Mesin ROCKWELL standart ASTM E 10 ISO 6506

Penelitian dilakukan dengan melakukan pengujian kekerasan pada benda kerja hasil pemotongan flame cutting. Pengujian kekerasan dilakukan deengan mengambil jarak $2 \mathrm{~mm}, 10 \mathrm{~mm}, 20 \mathrm{~mm}, 30 \mathrm{~mm}, 40 \mathrm{~mm}$ dan $50 \mathrm{~mm}$ dari tepi garis potong.

Specimen yang diuji telah mengalami tiga perlakuan yang berbeda yaitu : waktu pendinginan pada 10 detik, waktu pendinginan pada 25 detik dan waktu pendinginan pada 50 detik.

Diagram alir penelitian

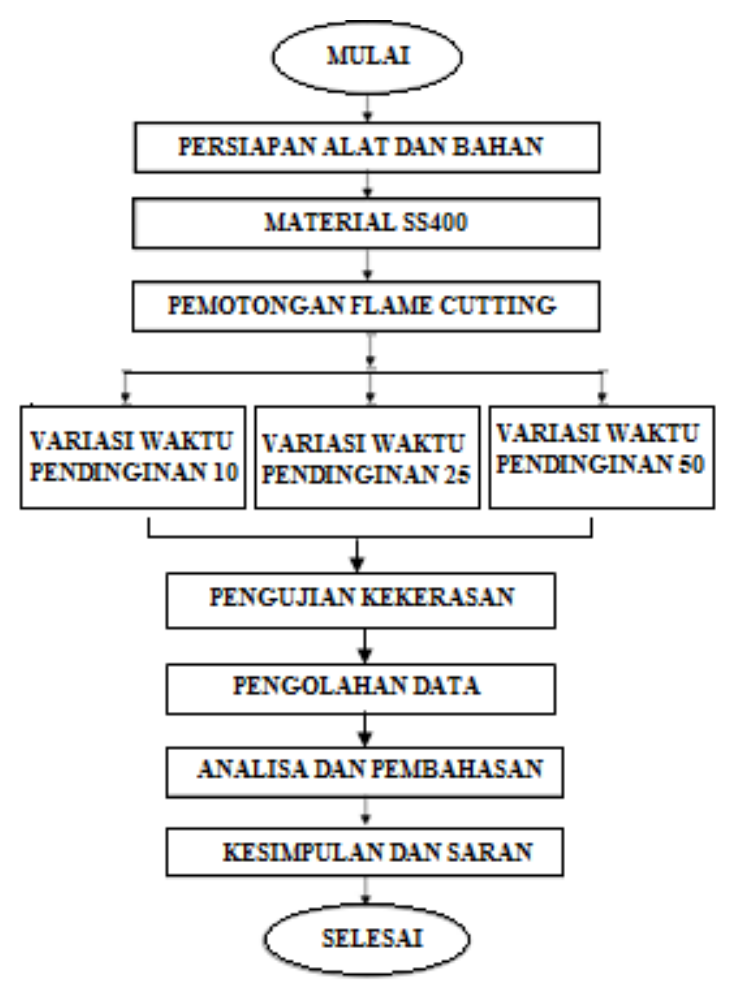

Gambar 1. Diagram alir penelitian 


\section{III.HASIL DAN PEMBAHASAN}

Dari data pengujian kekerasan didapatkan hasil sebagai berikut :

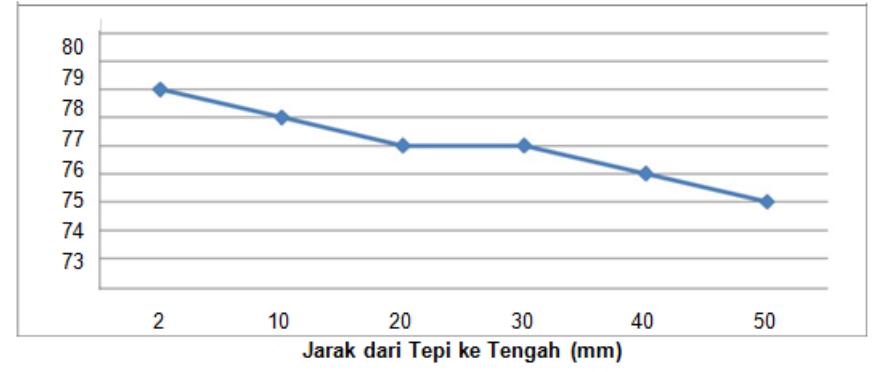

Gambar 2. Nilai Kekerasan Terhadap waktu Pendinginan Pada 10 second

Dari gambar 2. dapat dilihat bahwa kekerasan material SS 400 dengan waktu pendinginan 10 detik hasil pemotongan flame cutting CNC yang dilakukan 3 kali pengujian pembanding pada jarak tepi ketengah mempunyai kekerasan lebih besar, dari jarak $2 \mathrm{~mm}-50 \mathrm{~mm}$ disini selalu ada penurunan disetiap pengujian. Bisa dilihat pada grafik penurunan sefnifikan terjadi pada jarak 2 mm-20 mm, 30 mm-50 mm. Dimana penurunan ini terjadi dikarenakan kekerasan dari specimen semakin rendah selain itu juga jarak yang semakin jauh dengan daerah pemotongan, hal ini menyebabkan penyebaran panas hanya terfokus pada daerah sekitar pemotongan. Sehinga tingkat kekerasan menurun dengan kekerasan terendah $74 \mathrm{HRB}$ pada jarak 50 mm dan untuk nilai kekerasan tertinggi adalah $79 \mathrm{HRB}$ pada jarak $2 \mathrm{~mm}$.

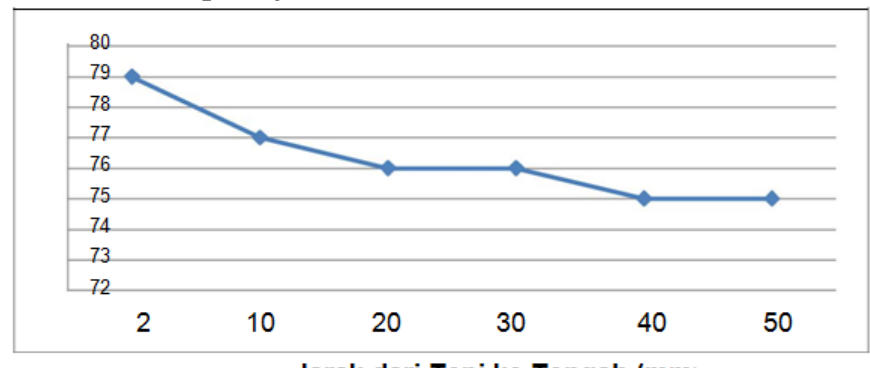

Jarak dari Tepi ke Tengah (mm)

Gambar 3. Nilai Kekerasan Terhadap waktu Pendinginan Pada 25 second

Dari gambar 3. dapat dilihat bahwa kekerasan material SS 400 dengan waktu pendinginan 25 detik hasil pemotongan flame cutting CNC yang dilakukan 3 kali pengujian pembanding pada jarak tepi ketengah mempunyai kekerasan lebih besar, dari jarak $2 \mathrm{~mm}-50 \mathrm{~mm}$ disini juga selalu ada penurunan disetiap pengujian. Bisa dilihat pada grafik penurunan sefnifikan terjadi pada jarak 2 mm-10 mm, $30 \mathrm{~mm}-40 \mathrm{~mm}$. Dimana penurunan ini terjadi dikarenakan kekerasan dari specimen semakin rendah selain itu juga jarak yang semakin jauh dengan daerah pemotongan, hal ini menyebabkan penyebaran panas hanya terfokus pada daerah sekitar pemotongan. Sehinga tingkat kekerasan menurun dengan kekerasan terendah $73 \mathrm{HRB}$ pada jarak 50 mm dan untuk nilai kekerasan tertinggi adalah $77 \mathrm{HRB}$ pada jarak $2 \mathrm{~mm}$.

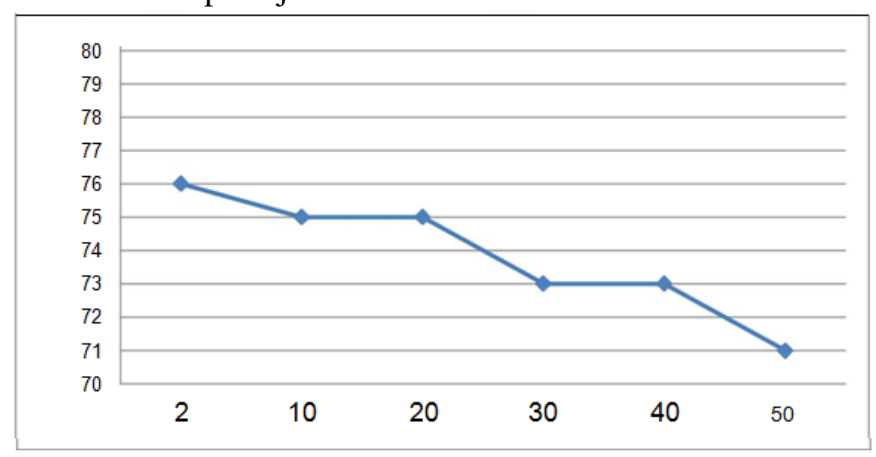

Jarak dari Tepi ke Tengah (mm)

Gambar 4. Nilai Kekerasan Terhadap waktu Pendinginan Pada 50 second

Dari gambar 4. dapat dilihat bahwa kekerasan material SS 400 dengan waktu pendinginan 50 mm hasil pemotongan flame cutting CNC yang dilakukan 3 kali pengujian pembanding pada jarak tepi ketengah mempunyai kekerasan lebih besar, dari jarak $2 \mathrm{~mm}-50 \mathrm{~mm}$ disini selalu ada penurunan disetiap pengujian. Bisa dilihat pada grafik penurunan sefnifikan terjadi pada jarak $2 \mathrm{~mm}-10 \mathrm{~mm}, 20 \mathrm{~mm}-30 \mathrm{~mm}$ dan $40 \mathrm{~mm}-50 \mathrm{~mm}$. Dimana penurunan ini terjadi dikarenakan kekerasan dari specimen semakin rendah selain itu juga jarak yang semakin jauh dengan daerah pemotongan, hal ini menyebabkan penyebaran panas 
hanya terfokus pada daerah sekitar pemotongan. Sehinga tingkat kekerasan menurun dengan kekerasan terendah 71 HRB pada jarak $50 \mathrm{~mm}$ dan untuk nilai kekerasan tertinggi adalah $76 \mathrm{HRB}$ pada jarak $2 \mathrm{~mm}$.

Dari semua hasil pengujian baik waktu pendinginan 10 detik, waktu pendinginan 25 detik dan waktu pendinginan 50 detik kemudian diambil nilai rata-rata dan diplot pada grafik berikut.

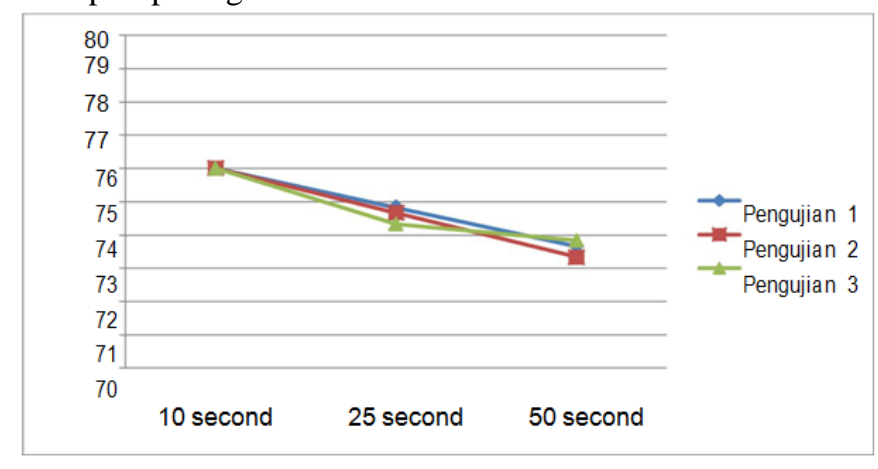

Waktu pendinginan

Gambar 5. Data nilai rata-rata uji kekerasan pada variasi waktu pendinginan 10 detik, 25 detik dan 50 detik

Dari gambar 5. dapat dilihat bahwa nilai kekerasan material SS 400 pada waktu pendinginan 10 detik dengan pengujian 3 pengulangan menghasilkan rata-rata kekerasan dari pengujian $1=76 \mathrm{HRB}$ pengujian $2=76 \mathrm{HRB}$, pengujian $3=76 \mathrm{HRB}$. Pada waktu pendinginan 25 detik menghasilkan rata-rata kekerasan dari pengujian $1=74,83 \mathrm{HRB}$, pengujian $2=74,66 \mathrm{HRB}$, pengujian $3=74,33 \mathrm{HRB}$. Dan waktu pendinginan 50 detik mengasilkan rata-rata kekerasan dari pengujian $1=73,66 \mathrm{HRB}$, pengujian $2=73,33 \mathrm{HRB}$, pengujian $3=7658 \mathrm{HRB}$.

\section{IV.KESIMPULAN}

\section{A. Kesimpulan}

Dari hasil penelitian Uji kekerasan pada material SS 400 dimana semakin besar kecepatan waktu pendinginan kekerasan mengalami penurunan. Jadi bahwa kekerasan material SS 400 dengan variasi waktu pendinginan 10 detik nilai rata - rata kekerasan lebih tinggi dengan nilai $76 \mathrm{HRB}$, disbanding, pendinginan 25 second yang hanya mempunyai nilai rata-rata kekerasan tertinggi 74,83 HRB dan 50 second yang mempunyai nilai rata - rata kekerasan tertinggi 73,83 HRB.

\section{B. Saran}

1. Bila melakukan pemotongan mengunakan pemotongan flame cutting $\mathrm{CNC}$ perlu perhatikan proses perlakuan panas dan pendingginannya.

2. Perlu pengujian berulang - ulang utuk mendapatkan nilai kekerasan yang lebih akurat dan menambah pengujian penelitian metode lain.

\section{DAFTAR PUSTAKA}

Cyrill Donaldson, George H. L. and V. C. Goold, “Tool Design”, 3rd edition, Mc Graw-Hill Publishing Co. Ltd, New Delhi, 1976. Geoffrey Boothroyd , “Fundamentals of Metal Machining Tool”, International Student Edition, 1981.

Krar, Oswald., and S.T. Amand "Technology of Machine Tool", $3^{\text {rd }}$ ed. Mc Graw-Hill Book Co., 1979.

Taufiq Rochim, “ Teori dan Teknologi Proses Pemesinan ”, Lab. Teknik Produksi, Jurusan Teknik Mesin, FTI, ITB, Bandung, 1993.

Taufiq Rochim, " Spesifik Metrologi dan Kontrol Kualitas Geometrik I " Laboratorium Teknik Produksi dan Metrologi Industri, Jurusan Teknik Mesin, FTI, ITB, Bandung, 2001. 